\title{
CONCORDÂNCIA VERBAL
}

\section{Joffre M. de Rezende ${ }^{1}$}

A concordância do verbo com o sujeito da oração apresenta, por vezes, algumas dificuldades com as quais tropeçamos na redação de artigos científicos.

Encontramos nas gramáticas a orientação necessária baseada em exemplos colhidos em textos de escritores clássicos (1).

Julgamos útil, entretanto, transpor para a linguagem médica as regras de concordância verbal daqueles casos que geralmente nos trazem dúvidas.

A regra básica é de que o verbo concorda com o sujeito em número e pessoa. Em determinadas construções, no entanto, quando se trata de sujeito composto, a condição de pluralidade depende de interpretação e, em muitos casos, admite-se a concordância tanto no singular como no plural. Damos, a seguir, alguns exemplos:

1. Os sujeitos na $3^{\text {a }}$. pessoa ligados pela conjunção $e$ exigem o verbo no plural: Ex.: Dieta $e$ exercício são essenciais ao diabético.

Tratando-se de palavras sinônimas ou que expressam a mesma ideia, o verbo deve ficar no singular.

Ex.: Habilidade e destreza revela $\mathrm{o}$ bom cirurgião.

2. Quando os sujeitos forem resumidos em uma palavra como tudo, nada, nenhum, o verbo ficará no singular.

Ex.: As náuseas, a febre, a dor na fossa ilíaca direita, o sinal de Blumberg positivo, tudo indicava tratar-se de apendicite aguda.

3. Quando os sujeitos vierem após o verbo, admite-se a concordância com o mais próximo, no singular, ou com a totalidade, no plural.

1 Professor Emérito da Universidade Federal de Goiás.

Endereço para correspondência: E-mail: joffremr@ig.com.br http://usuarios.cultura.com.br/jmrezende

Recebido para publicação em: 30/12/2012 
Ex.: No singular - Na hemiplegia, observa-se contratura muscular, marcha ceifante e sinal de Babinski.

Ex.: No plural - Confirmaram a hipótese diagnóstica a ultrassonografia e a tomografia computadorizada.

4. Sendo o sujeito o pronome quem, o verbo fica de preferência no singular.

Ex.: No hospital são as auxiliares de enfermagem quem mede a temperatura $\mathrm{e}$ toma a pressão arterial dos doentes internados.

Admite-se também a concordância com a palavra que antecede o pronome.

Ex.: Fui eu quem operei o paciente, em vez de fui eu quem operou o paciente.

5. Nos casos de sujeitos da $3^{\text {a }}$. pessoa do singular, ligados pela conjunção nem, o verbo poderá ficar no singular ou no plural.

Ex.: No singular - Nem a intubação traqueal, nem a massagem cardíaca reanimou o paciente.

Ex.: No plural-Nem os analgésicos comuns, nem os opiáceos aliviaram a dor.

6. Nos casos de sujeitos ligados pela partícula com, o verbo poderá ficar no singular ou no plural. Usa-se o singular quando se pretende realçar a ação do primeiro deles e o plural para indicar igualdade de cooperação entre os sujeitos.

Ex.: No singular - O professor com seus assistentes operou o paciente.

Ex.: No plural-O professor com seus assistentes operaram o paciente.

7. Os sujeitos ligados por assim como, tanto...como, não só...mas também pedem o verbo no plural.

Ex.: A anamnese assim como o exame físico são imprescindíveis em qualquer especialidade.

Ex.: Tanto a história clínica como a icterícia e o prurido cutâneo sugerem tratar-se de colestase extra-hepática.

Ex.: Não só os corticóides, mas também imunodepressores como a azatioprina estão indicados no tratamento da doença de Crohn.

8. Estando os dois sujeitos ligados por bem como, o verbo concorda com o primeiro.

Ex.: Este antibiótico, bem como todos os macrolídeos, é eficaz nas infecções urinárias.

9. Quando a expressão um e outro (uma e outra) figura como sujeito da frase, o verbo tanto pode estar no singular como no plural.

Ex.: No singular - Um e outro tratamento pode ser empregado.

Ex.: No plural-Uma e outra técnica foram usadas, ambas com bons resultados.

10. Quando se trata do verbo ser, a concordância se faz de preferência com o predicativo, salvo se o sujeito for uma pessoa. Neste caso o verbo fica no singular. Ex.: A causa da hipopotassemia foram os vômitos.

11. Com o sujeito representado pela expressão mais de um (mais de uma), é preferível o verbo no singular. Contudo, também se usa no plural.

Ex.: No singular - Mais de um médico cuidou deste paciente.

Ex.: No plural-Mais de um pesquisador chegaram à mesma conclusão. 
12. Com a expressão mais de dois (mais de três etc.), o plural é obrigatório. Com a expressão um dos...que (uma das...que), o verbo pode ser usado indiferentemente no singular ou no plural.

Ex.: No singular - Carlos Chagas foi um dos cientistas que mais contribuiu para a projeção da medicina brasileira no exterior.

Ex.: No plural - A descoberta dos raios-X foi um dos acontecimentos mais notáveis que marcaram o início da era tecnológica da medicina.

13. O sujeito representado por um substantivo coletivo seguido de complemento no plural admite o verbo indiferentemente no singular ou no plural.

Ex.: No singular - Grande número de publicações médicas brasileiras não se encontra indexada.

Ex.: No singular - A maioria dos estudantes tomou parte na manifestação de protesto.

Ex.: No plural - Grande parte dos recursos destinados à saúde são mal aplicados,

Ex.: No plural - A maioria dos médicos em atividade possuem algum tipo de emprego e trabalham em mais de um local.

14. Os sujeitos ligados pela conjunção $o u$ admitem o verbo tanto no singular como no plural. $\mathrm{O}$ verbo ficará obrigatoriamente no singular se os sujeitos forem sinônimos.

Ex.: A tripanossomíase americana ou doença de Chagas é endêmica nos países sul-americanos.

Há outras particularidades de concordância verbal que não foram aqui incluídas.

Limitamo-nos aos casos mais comuns e de maior interesse para a linguagem médica.

\section{REFERÊNCIAS}

1. Torres AA. Moderna gramática expositiva da língua portuguesa, 1962. p.138-156.

Obs. Publicado no livro do autor Linguagem Médica, 4a . ed. Goiânia, Ed. Kelpes, 2011. 